\title{
HUBUNGAN KINERJA KEUANGAN BANK SYARIAH, ORIENTASI PASAR, ORIENTASI PEMBELAJARAN, DAN MODAL RELASIONAL
}

\author{
Moh Khoiruddin \\ Dosen Fakultas Ekonomi Universitas Negeri Semarang (UNNES) \\ mobkhoiruddin@yahoo.co.id \\ Andhi Wijayanto \\ Dosen Fakultas Ekonomi Universitas Negeri Semarang (UNNES) \\ andhi.w@staff.unnes.ac.id
}

\begin{abstract}
This study aims to determine the relationship of the financial performance of Islamic banks, market orientation, learning orientation, and relational capital. By knowing the kind of relationship would be beneficial for improving the financial performance of Islamic banks which have distinctive core business. The population in this study was the manager of Islamic banks in the province of Central Java. With purposive random sampling, 119 samples are obtained. SEM analysis results show the effect of learning orientation on market orientation, market orientation effect on relational capital, relational capital effects on the financial performance, the effect of learning orientation on financial performance, the effect of market orientation on financial performance is significant. Goodness of Fit value of the model is quite satisfactory.
\end{abstract}

Keywords: Financial Performance, Market Orientation, Relational Capital

\begin{abstract}
Abstrak
Penelitian ini bertujuan mengetabui bubungan kinerja keuangan bank syariah, orientasi pasar, orientasi pembelajaran, dan modal relasional. Dengan diketabuinya bentuk hubungan tersebut akan bermanfaat bagi upaya peningkatan kinerja keuangan bank syariah yang memiliki core business khas. Populasi dalam penelitian ini adalah manajer bank syariah di provinsi Jawa Tengah. Dengan purposive random sampling, didapatkan 119 sampel. Hasil analisis SEM menunjukkan pengarub orientasi pembelajaran terhadap orientasi pasar, pengarub orientasi pasar terhadap modal relasional, pengarub modal relasional terbadap kinerja keuangan, pengarub orientasi pembelajaran terbadap kinerja keuangan, pengarub orientasi pasar terhadap kinerja keuangan adalah signifikan. Nilai Goodness of Fit model cukup memuaskan.
\end{abstract}

Kata kunci: Kinerja Keuangan, Orientasi Pasar, Modal Relasional 


\section{Pendahuluan}

Keberadaan bank syariah di Indonesia dimulai sejak tahun 1992 dengan berdirinya Bank Muamalat Indonesia. Mulai saat itu di Indonesia dikenal terdapat dua jenis bank jika dilihat dari prinsip dasar yang melandasi operasionaliasi bank, yaitu bank konvensional yang berbasis pada konsep interest, dan bank syariah yang berbasis pada non interest. Tingkat pertumbuhan bank syariah cukup pesat meskipun secara umur masih tergolong muda. Sepanjang keberadaannya bank syariah belum pernah ada yang dilikuidasi sebagaimana terjadi pada banyak bank konvensional, terutama pada masa-masa krisis ekonomi-keuangan di sepanjang periode 1992 hingga 2011. Dalam lima tahun terakhir tingkat pertumbuhan bank syariah nasional di atas tingkat pertumbuhan bank konvensional. Dalam catatan statistik, tidak pernah terjadi penurunan jumlah bank syariah, unit usaha syariah, maupun bank pembiayaan syariah yang beroperasi di Indonesia. Demikian pula tidak ada penututupan bank syariah karena likuidasi dari mulai pemunculannya pertama kali dalam industri perbankan nasional pada tahun 1992 hingga sekarang ini. Dalam periode yang sama data untuk jumlah bank konvensional menunjukkan penurunan, yaitu di tahun 2000 sebanyak 151 bank umum menjadi tinggal 120 bank per Nopember 2011, meskipun jumlah kantornya meningkat sebesar 2,3 kali lipat.

Tabel 1 menunjukkan bahwa kecukupan modal bank syariah sebagai salah satu indikator kesehatan bank yang diukur dengan rasio CAR (Capital Adequacy Ratio) menunjukkan jauh di atas 8 persen sebagaimana ketentuan minimal yang ditetapkan. Bahkan bila dilihat dari waktu ke waktu dari mulai 2005 hingga 2011 capaian CAR masih di atas 10 persen, dan rata-ratanya masih di atas 12 persen. Hal itu menunjukkan bahwa permodalan bank syariah dengan mempertimbangkan aktiva tertimbang menurut risiko cukup kuat; 
Tabel: 1

Rasio Keuangan Bank Syariah

\begin{tabular}{lccccccc}
\hline \multicolumn{7}{c}{ Rasio Keuangan Bank Umum Syariah dan Unit Usaha Syariah } \\
\multicolumn{1}{c}{ Rasio } & 2005 & 2006 & 2007 & 2008 & 2009 & 2010 & 2011 \\
\hline CAR & $12.41 \%$ & $13.73 \%$ & $10.67 \%$ & $12.81 \%$ & $10.77 \%$ & $16.25 \%$ & $15.30 \%$ \\
ROA & $1.35 \%$ & $1.55 \%$ & $2.07 \%$ & $1.42 \%$ & $1.48 \%$ & $1.67 \%$ & $1.75 \%$ \\
ROE & $27.58 \%$ & $28.45 \%$ & $40.38 \%$ & $38.79 \%$ & $26.09 \%$ & $17.58 \%$ & $17.43 \%$ \\
NPF & $2.82 \%$ & $4.75 \%$ & $4.05 \%$ & $1.42 \%$ & $4.01 \%$ & $3.02 \%$ & $3.50 \%$ \\
FDR & $97.75 \%$ & $98.90 \%$ & $99.76 \%$ & $103.65 \%$ & $89.70 \%$ & $89.67 \%$ & $94.97 \%$ \\
BOPO & $78.91 \%$ & $76.77 \%$ & $76.54 \%$ & $81.75 \%$ & $84.39 \%$ & $80.54 \%$ & $77.54 \%$ \\
\hline
\end{tabular}

Sumber Sumber: Bank Indonesia 2005-2011

Sementara CAR bank konvensional dalam periode yang sama rata-ratanya tidak sampai pada angka 13 persen, bahkan tidak sedikit bank konvensional CAR-nya masih berada di bawah angka 12 persen pada periode tersebut. Return on Equity (ROE) bank syariah yang menunjukkan kemampuan bank mendapatkan pendapatan dari modal sendirinya mengalami penurunan dari tahun 2005 hingga tahun 2011. Hal ini bisa diinterpretasikan bahwa penggunaan dana pihak ketiga dalam operasi bank syariah semakin besar. Jumlah dana pihak ketiga dalam struktur modal bank syariah proporsinya mengalami kenaikan. Dengan kata lain semakin banyak masyarakat yang menyimpan uangnya di bank syariah.

Kinerja bank syariah Indonesia dari sisi perkembangan Total Asset telah mengalami pertumbuhan hampir lima kali lipat selama periode 2005-2011 (Bank Indonesia, 2011). Hal itu dapat dilihat dari total asetnya pada tahun 2005 per Desember sebesar Rp 20.880 miliar, sementara pada tahun 2011 per April menjadi sebesar Rp 100.568 miliar. Kemampuan bank syariah dalam menghasilkan pendapatan dari total asetnya yang ditunjukkan oleh ROA (Return on Asset) bila dilihat dari tahun 2005 hingga 2011, dari trend-nya mengalami kenaikan, yaitu dari 1,35 persen menjadi 1,75 persen. Bahkan sejak tahun 2010 hingga 2011 ROA bank syariah ini berada di atas 1,5 persen, dan secara rata-rata capaian ROA bank syariah di atas ROA bank konvensional. Return on Assets (ROA) bank syariah dalam kurun waktu 2005 hingga 2011 dalam posisi ratarata stabil di atas 1,4 persen. Angka rasio tersebut masih relatif kecil, namun dalam dua tahun terakhir posisinya lebih baik bila 
dibandingkan dengan capaian bank konvensional. Kecilnya rasio ini karena masih relatif kecilnya aset bank syariah, dan kurang optimalnya pemanfaatan aset dalam operasi bank syariah. Khusus di provinsi Jawa Tengah, pada Triwulan1-2011 (posisi Februari 2011), perkembangan bank umum syariah (BUS) dan BPR syariah (BPRS) di Jawa Tengah masih menunjukkan pertumbuhan yang cukup tinggi. Aset tumbuh sebesar 53,37\% (yoy) menjadi Rp5,53 triliun, meningkat dibandingkan triwulan IV-2010 yang tumbuh sebesar 51,45\% (yoy), walaupun relatif melambat dibandingkan triwulan yang sama tahun sebelumnya yang tumbuh mencapai $60,71 \%$ (yoy). Secara triwulanan, aset tumbuh sebesar $4,70 \%$ (qtq), lebih kecil dibandingkan pertumbuhan triwulan sebelumnya yang sebesar 10,36\% (yoy).

Sementara bila dilihat dari rasio NPF (Non Performing Financing) nasional yang menunjukkan sejauhmana pembiayaan yang digulirkan bank syariah bermasalah menunjukkan kecenderungan meningkat dari tahun 2005 hingga 2011. Namun demikian dari tahun 2001 hingga 2011 secara umum masih berada pada kisaran rasio NPF di bawah 4 persen. Kondisi yang berbeda bila dibandingkan dengan bank umum konvensional, nilai NPF bank syariah masih di bawah NPL bank konvensional, bahkan tidak sedikit bank konvensional yang mencapai nilai NPL di atas 5 persen. Sejak tahun 2010 hingga 2011, data bulanan NPF menunjukkan hampir 100 persen bank syariah mencapai kurang dari 5 persen. Sementara pada periode yang sama, sekitar 10 persen bank konvensional capaian NPL-nya di atas 5 persen. Hal ini menunjukkan bahwa jumlah pembiayaan/kredit bermasalah lebih besar terjadi pada bank umum konvensional.

Selanjutnya bila dilihat dari FDR (Financing Debt Ratio), yaitu rasio yang menunjukkan perbandingan besarnya pembiayaan yang digulirkan dengan jumlah dana pihak ketiga yang berhasil dihimpun, bank syariah menunjukkan rasio yang sangat besar (di atas 90 persen) sepanjang tahun 2005 hingga 2011. Hal tersebut menunjukkan bahwa hampir semua dana yang berhasil dihimpun dari masyarakat dikembalikan lagi ke masyarakat yang membutuhkan melalui berbagai skim pembiayaan yang diberikan, artinya tidak terjadi kemandegan dana yang besar, atau tidak terjadi 
pelarian dana pihak ketiga dalam pasar keuangan. Keadaan seperti itu akan membawa kemanfaatan berganda terutama di sektor riil. Berbeda dengan yang ada di bank konvensional, LDR (loan to deposit ratio) yang setara dengan FDR di bank syariah, ternyata menunjukkan angka yang rendah, bahkan angkanya di bawah 50 persen. Kondisi itu menunjukkan bahwa banyak dana pihak ketiga yang berhasil dihimpun bank tidak bergulir kembali dalam bentuk kredit yang diberikan bank kepada masyarakat, sehingga sedikit membawa manfaat berganda dibandingkan yang dilakukan bank syariah. Hal seperti itu terjadi karena tidak lepas dari karakteristik dasar dari dana pihak ketiga yang dihimpun oleh masing-masing bank. Bank konvensional dalam menggali dana masyarakat dengan menggunakan konsep hutang sebagai dasarnya dengan interest based. Sementara bank syariah menggunakan konsep equity sebagai dasarnya dengan profit and loss sharing dan fee based.

Di Provinsi Jawa Tengah FDR pada triwulan IV-2010 mengalami peningkatan dari 129,42\% pada triwulan 1-2011 menjadi 139,41\%. Namun demikian, kualitas pembiayaan mengalami sedikit penurunan, yang ditunjukkan oleh kenaikan rasio pembiayaan non lancar (Non Performing Financing, NPF) dari 2,32\% pada triwulan IV-2010 menjadi 2,82\% pada triwulan 1-2011, dan $3,12 \%$ pada triwulan 1-2012. Sementara, NPL bank konvensional pada triwulan 1-2011 sebesar 2,10\%, dan pada triwulan 1-2012 sebesar 2,33\%.

Kinerja perusahaan merupakan konstruk (faktor) yang umum digunakan untuk mengukur dampak dari sebuah strategi perusahaan. Strategi perusahaan selalu diarahkan untuk menghasilkan kinerja baik berupa kinerja pemasaran maupun kinerja keuangan. Thomas Sowell (2004) menyarankan bahwa keinginan mendapatkan laba menempatkan tekanan yang terus menerus terhadap pemilik untuk memonitor segala hal yang terjadi dalam bisnis dan segala hal yang terjadi di pasar untuk produk bisnis. Kinerja finansial superior merupakan refleksi dari nilai sumber daya perusahaan (Srivastava, Fahey, \& Christiansen, 2001). Noble, Sinha dan Kumar (2002) menemukan bahwa orientasi persaingan dan fokus merek nasional secara positif terkait dengan tujuan ROA dan keuntungan atas penjualan (ROA). Nikoomaram \& Ma'atoofi (2011) menemukan 
Learning Orientation mempengaruhi secara signifikan Market Orientation, dan Market Orientation berhubungan positif dengan profitabilitas, sales, dan ROI.

Orientasi pasar adalah budaya bisnis yang menempatkan prioritas tertinggi pada penciptaan keuntungan dan pemeliharaan nilai unggul pelanggan, dengan mempertimbangkan para stakeholder (Ellis, 2006). Akinova (2000) menegaskan bahwa orientasi pasar menyediakan norma perilaku organisasional, diseminasi, dan responsif terhadap informasi pemasaran.

Memahami hubungan antara orientasi pasar dan kinerja dalam industri menjadi sangat penting untuk dipelajari. Dari sekian banyak hasil penelitian empiris hubungan antara orientasi pasar dan kinerja bisnis menunjukkan inkonsistensi dalam hubungan dan menunjukkan bahwa masalah ini merupakan permasalahan yang belum terpecahkan (Deshpande \& Farley 1998). Misalnya, Ruekert (1992), Slater dan Narver (1994), Ellis (2006) menemukan langsung hubungan positif antara orientasi pasar dengan kinerja bisnis, dan Gebhardt, Carpenter dan Sherry (2006) melaporkan tidak ada hubungan langsung antara orientasi pasar dan kinerja bisnis, sementara Narver dan Slater (1990) Jaworski \& Kohli (1993), Kara et. al, (2004). dan Kirca dan Beaden (2005) menemukan hasil yang beragam hubungan orientasi pasar dan kinerja bisnis di perusahaan manufaktur dan jasa.

Penelitian Narver dan Slater (1993) menunjukkan adanya satu hubungan positif antara orientasi pasar dan kinerja. Appiah-Adu \& Ranchod (1998) dari survey industri yang dilakukan terhadap 62 perusahaan bio industri di Inggris dengan menggunakan ukuran orientasi pasarnya Narver dan Slater (1990) menunjukkan pengaruh positif signifikan orientasi pasar pada pertumbuhan market share, profit margin dan semua kinerja. Chan Hung Ngai \& Ellis (1998) menemukan orientasi pasar signifikan berpengaruh positif terhadap relative profitability. Homburg \& Pflesser (2000) menyatakan bahwa orientasi pasar berpengaruh signifikan positif terhadap financial performance. Narver \& Slater (1990) dengan menggunakan sama pel II, hasilnya orientasi pasar signifikan berpengaruh positif terhadap return on Asset (ROA). Slater \& Narver (2000) signifikan berpengaruh positif terhadap ROI. 
Penelitian Asikhia (2010), dengan menggunakan Narver and Slater 's scale untuk pengukuran orientasi pasar yang diperluas, hasilnya menunjukkan bahwa terdapat hubungan positif signifikan antara orientasi pasar dan kinerja bank. Kinerja bank sangat tinggi dicapai melalui adopsi orientasi pasar yang dilakukan oleh bank. Namun demikian, hasil survey cross-sectional 950 perusahaan jasa di Inggris yang dilakukan Caruana, Pitt \& Berthon (1999) menggunakan ukuran market oriented-nya Jaworski \& Kohli (1993) menunjukkan pengaruh tidak signifikan market orientation (MO) terhadap kinerja bisnis.

Penelitian Lado dan Olivares (2000) menemukan bahwa terdapat dampak positif orientasi pembelajaran terhadap kinerja inovasi, baik di pasar Amerika maupun di Uni Eropa. Hasil penelitian menunjukkan bahwa orientasi pembelajaran memiliki dampak positif yang signifikan pada orientasi pelanggan dan orientasi pesaing. Selain itu, orientasi pembelajaran memiliki dampak signifikan tidak langsung (dimediasi) pada kinerja organisasi.

Orientasi pembelajaran merupakan hal penting bagi perusahaan untuk dapat menjalin hubungan/relasional dengan stakeholder dengan baik. Modal relasional adalah himpunan semua hubungan-hubungan pasar, kekuatan hubungan dan kerjasama mapan antara perusahaan, lembaga dan orang yang berasal dari rasa memiliki yang kuat dan tingkat kerjasama yang tinggi di antara individu dan institusi sejenis (Capello dan Faggàn 2005). Mengingat keterbatasan sumber daya, perusahaan dapat memanfaatkan sumber daya relasional untuk akuisisi suatu pengetahuan dengan menciptakan hubungan spesifik dan berbagi pengetahuan secara rutin (Yli-Renko et al, 2001).

Perbankan syariah merupakan industri keuangan yang mengalami pertumbuhan tercepat. Ukurannya (size) telah tumbuh dari beberapa ratus ribu dollar di tahun 1975 menjadi ratusan miliar dollar pada 2005. Praktik bank syariah sekarang tidak saja terbatas di negara-negara Arab atau muslim, namun telah menyebar dari Timur ke Barat, melalui semua jalan termasuk dari Indonesia dan Malaysia menuju Eropa dan Amerika (Ariff, 1988). Tidak hanya itu, faktanya adalah bahwa banyak bank konvensional, termasuk 
sejumlah bank-bank multinasional utama di Barat telah mulai menggunakan teknik-teknik bank syariah. Meskipun demikian fakta lain menunjukkan bahwa hingga sekarang bila aset dari semua bank syariah dikumpulkan jadi satu, besarnya tidak lebih besar dibandingkan dengan total aset 50 bank terbesar dunia, aset bank syariah terbesar sama dengan 1 persen aset dari bank terbesar dunia.

Di Indonesia, dalam catatan statistik, tidak pernah terjadi penurunan jumlah bank syariah, unit usaha syariah, maupun bank pembiayaan syariah yang beroperasi. Demikian pula tidak ada penututupan bank syariah karena likuidasi dari mulai pemunculannya pertama kali dalam industri perbankan nasional di tahun 1992 hingga sekarang dapat dilihat pada table di bawah;

Tabel: 2

\section{Perkembangan Jumlah Jaringan Kantor Bank Syariah}

\begin{tabular}{|c|c|c|c|c|c|c|c|c|c|c|c|c|}
\hline Kelom & 2000 & & 2002 & 2003 & 2004 & 2005 & 2006 & 2007 & 2008 & 2009 & 2010 & 2011 \\
\hline BankUm & 2 & 2 & 2 & 2 & 3 & 3 & 3 & 3 & 5 & 6 & 11 & 11 \\
\hline & 3 & 3 & 6 & 8 & 15 & 19 & 20 & 26 & 27 & 25 & & 24 \\
\hline & 62 & 96 & 127 & 299 & 401 & 504 & 531 & 597 & 822 & 998 & 1477 & 1737 \\
\hline & - & - & - & - & - & - & 456 & 1195 & 1470 & 1929 & 1277 & 1277 \\
\hline & 79 & 81 & 83 & 84 & 88 & 92 & 105 & 114 & 131 & 138 & 150 & 155 \\
\hline & 79 & 81 & 83 & 84 & 88 & 92 & 105 & 185 & 202 & 225 & 286 & 364 \\
\hline & 151 & 145 & 141 & 138 & 133 & 131 & 130 & 130 & 124 & 121 & 122 & 120 \\
\hline $3 \mathrm{U}$ & 6547 & 6765 & 7001 & 7730 & 7020 & 8236 & 9110 & 9680 & 1086 & 1283 & 1383 & 147 \\
\hline & 2419 & & 214 & 214 & 215 & 200 & 1880 & 1817 & 1772 & 1733 & 1706 & 1684 \\
\hline & 2482 & 243 & 274 & 3290 & 3507 & 3110 & 3173 & 3250 & 3367 & 3644 & 3910 & 4140 \\
\hline
\end{tabular}

Sumber: Bank Indonesia, 2003-2012

Tabel 2 menunjukkan dalam periode yang sama, data jumlah bank umum konvensional menunjukkan penurunan, yaitu di tahun 2000 sebanyak 151 bank umum menjadi tinggal 120 bank per Nopember 2011, meskipun jumlah kantornya meningkat sebesar 2,3 kali lipat. Pada periode krisis ekonomi 2001-2002 dan 2007-2008 data jumlah bank konvensional terlihat mengalami penurunan yang tajam dibandingkan dengan periode lainnya. Jumlah bank umum pada periode tersebut berkurang sekitar 6 bank. Hal yang hampir 
sama juga terjadi pada Bank Perkreditan Rakyat (BPR).

Masalah yang muncul dalam penelitian ini berawal dari adanya research gap, yaitu pertama adanya perbedaan hasil penelitian mengenai hubungan kinerja keuangan dan orientasi pasar. Kedua, adanya perbedaan hasil penelitian pengaruh orientasi pembelajaran terhadap kinerja keuangan. Selanjutnya, masalah penelitian ini juga karena adanya fenomena bank syariah di Indonesia yang muncul dengan sejumlah keunikan dan prestasi besar dalam industri perbankan. Dengan pertimbangan tersebut, maka diperlukan adanya studi lebih lanjut untuk mengkaji masalah tersebut. Adanya keterbatasan waktu dan biaya menjadikan penelitian ini hanya terbatas pada 119 sampel bank syariah yang beroperasi di Propinsi Jawa Tengah. Bertitik tolak dari apa yang sudah diuraikan di atas maka masalah penelitian yang diangkat didalam studi ini adalah: "Bagaimana membangun sebuah model untuk meningkatkan kinerja keuangan perbankan syariah melalui pendekatan orientasi pemasaran, orientasi pembelajaran, dan modal relasional pada perbankan syariah dan unit usaha syariah di Propinsi Jawa Tengah?"

\section{Kinerja Keuangan, Orientasi Pasar, Orientasi Pembelajaran, dan Modal Relasional}

Asikhia (2010) dalam penelitiannya tentang orientasi pasar menggunakan kinerja bisnis. Kinerja bisnis tersebut terbagi menjadi kinerja keuangan dan kinerja pemasaran. Kinerja keuangan digunakan dengan memasukkan sejumlah dimensi keuntungan (profitability dimension) yang meliputi kepuasan terhadap pendapatan investasi perusahaan, posisi keuntungan bersih perusahaan relatif terhadap persaingan, posisi return on investment (ROI) relatif terhadap pesaing, kepuasan terhadap pendapatan penjualan (return on sales/ ROS), serta posisi likuiditas keuangan terhadap persaingan.

Dalam literatur, orientasi pasar telah ditetapkan dari tiga perspektif: (1) Kultur organisasional (Deshpande, Farley, dan Webster, 1993; Homburg dan Pflesser, 2000; Narver dan Slater, 1990), (2) Perilaku organisasional (Kohli dan Jaworski, 1990), dan (3) Berdasar sistem. Setelah beberapa tahun perdebatan mengenai orientasi pasar, hanya dua perspektif yang secara luas dipakai dalam literatur 
strategi pasar. Pertama adalah perspektif kultural Narver dan Slater (1990) dan yang kedua adalah perspektif perilaku Jaworski dan Kohli (1990). Orientasi pasar menyediakan kerangka kerja untuk pengembangan strategi pemasaran yang efektif, dengan fokus pada penciptaan nilai proposisi pelanggan unggul dibandingkan yang ditawarkan oleh pesaing (Day 1994).

Orientasi pembelajaran merupakan cara organisasi memandang lingkungannya, baik internal maupun eksternal, dan bertindak demi kepentingan mereka. Sumber daya yang mempunyai kekuatan besar untuk menciptakan keunggulan bersaing salah satunya bisa diciptakan dalam organisasi melalui orientasi pembelajaran (learning orientation). Sinkula et al. (1997) menyarankan bahwa organisasi merupakan pelajar/learner yang kompeten dikenal sebagai organisasi pembelajaran. Operasionalisasi dari orientasi pembelajaran Sinkula et al., (1997) merekomendasikan komitmen untuk mempelajari, berbagi pandangan dan atau tujuan, serta berpikiran terbuka (pada saat menunjukkan reliabilitas dan validitas). Komitmen pada pendekatan untuk pembelajaran, pandangan bersama, dan berpikiran terbuka kepada pelanggan dan pesaing akan menggerakkan organisasi menuju pencapaian sasaran kinerja bisnis. Pengetahuan menjadi semakin penting bagi organisasi, secara sederhana karena digunakan untuk mengerjakan pekerjaan organisasi yang diperlukan (Schwandt \& Marquardt, 2000). Dengan tujuan untuk bertahan dan berkembang, maka organisasi perlu belajar lebih cepat dan menunjukkan kecenderungan untuk beradaptasi dengan perubahan lingkungan (Schwandt \& Marquardt, 2000).

Modal relasional biasa dikenal juga dengan external capital dan customer capital, menunjukkan hubungan atau jaringan kerja yang diasosiasikan dalam kepuasan dan loyalitas perusahaan yaitu mencakup pengetahuan channel-channel pasar, konsumen, hubungan supplier dan customer, dan asosiasi industri dan pemahaman dampak kebijakan publik. Esensi modal relasional/ konsumen terletak pada pengetahuan yang melekat dalam hubungannya dengan lingkungan eksternal perusahaan dan tidak berhubungan dengan pengetahuan yang melekat dalam diri seseorang atau modal insani. Modal relasional didefinisikan sebagai 
himpunan semua hubungan-hubungan pasar, kekuatan hubungan dan kerjasama mapan antara perusahaan, lembaga dan orangyang berasal dari rasa memiliki yang kuat dan tingkat kerjasama yang tinggi di antara individu dan institusi sejenis (Capello dan Faggàn 2005).

\section{Hubungan antara Orientasi Pasar dan Kinerja Keuangan}

Orientasi pasar adalah budaya bisnis yang menempatkan prioritas tertinggi pada penciptaan keuntungan dan pemeliharaan nilai unggul pelanggan, dengan mempertimbangkan para stakebolder (Ellis, 2006). Akinova (2000) menegaskan bahwa orientasi pasar menyediakan norma perilaku organisasional, diseminasi, dan responsif terhadap informasi pemasaran. (Deshpande, Farley dan Webster 1993; Kohli \& Jaworski 1990; Narver dan Slater 1990). Selain itu, Hunt dan Morgan (1995) menyatakan bahwa budaya yang berorientasi pasar akan mengantarkan posisi keunggulan kompetitif yang berkelanjutan, sehingga kinerja keuangan unggul dalam jangka panjang.

Chan Hung Ngai \& Ellis (1998) menemukan orientasi pasar signifikan berpengaruh positif terhadap relative profitability. Gray, Matear, Boshoff \& Matheson (1998) menemukan orientasi pasar signifikan berpengaruh positif terhadap return on investment (ROI). Homburg \& Pflesser (2000) menyatakan bahwa orientasi pasar berpengaruh signifikan positif terhadap financial performance. Langerak (2001b) juga menemukan orientasi pasar signifikan berpengaruh positif terhadap financial performance. Narver \& Slater (1990) menggunakan sample I, hasilnya orientasi pasar signifikan berpengaruh negatif terhadap return on Asset (ROA). Narver \& Slater (1990) dengan menggunakan sample II, hasilnya orientasi pasar signifikan berpengaruh positif terhadap return on Asset (ROA). Slater \& Narver (2000) Signifikan berpengaruh positif terhadap ROI. Penelitian Asikhia (2010), dengan menggunakan Narver and Slater's scale untuk pengukuran orientasi pasar yang diperluas, hasilnya menunjukkan bahwa terdapat hubungan positif signifikan antara orientasi pasar dan kinerja bank. Kinerja bank sangat tinggi dicapai melalui adopsi orientasi pasar yang dilakukan oleh bank. Namun demikian, hasil survey cross-sectional 950 perusahaan jasa di Inggris 
yang dilakukan Caruana, Pitt \& Berthon (1999) menggunakan ukuran market oriented-nya Jaworski \& Kohli (1993) menunjukkan pengaruh tidak signifikan market orientation (MO) terhadap kinerja bisnis. Sementara, profitability adalah variabel kinerja yang paling umum digunakan untuk mempelajari dimensi kinerja perusahaan (Capon, Farley, and Hoenig 1990). Oleh karena itu hipotesis yang diajukan adalah, H1: Orientasi Pasar berpengaruh terhadap Kinerja Keuangan

\section{Hubungan antara Orientasi Pasar dan Modal Relasional}

Penjualan berbasis orientasi pelanggan adalah derajat di mana tenaga penjualan mempraktekkan konsep marketing dengan cara mencoba menolong pelanggan dalam memutuskan pembelian yang akan memenuhi kebutuhan pelanggan. Perusahaan yang berorientasi pelanggan dituntut untuk mengakuisisi dan mengasimilasi informasi-informasi yang penting untuk merancang dan menjalankan strategi-strategi pemasaran yang memberikan kinerja yang memuaskan pelanggan. Oleh karena itu, semua hubungan dengan pelanggan menuntut perilaku sopan dan efektif. Tuntutan ini membawa konsekuensi pada pembentukan pola perilaku yang kemudian menjadi kebiasaan. Oleh karena itu hipotesis yang diajukan adalah, H2: Orientasi Pasar berpengaruh terhadap Modal Relasional

\section{Hubungan antara Orientasi Pembelajaran dan Orientasi Pasar}

Orientasi pembelajaran yang mencakup kompetensi sosial dan kompetensi profesional telah diteliti dalam konteks orientasi pasar dan nilai yang dirasakan (Baker \& Sinkula et al., 1999; Kohli \& Jaworski, 1990; Slater \& Narver, 1995). Meskipun terkait, orientasi pasar dan orientasi pembelajaran merupakan dua karakteristik organisasional yang berbeda (Baker \& Sinkula et al., 1999; Sinkula et al., 1997). Suatu karakteristik kultural dari suatu organisasi pembelajaran adalah yang memungkinkan akuisisi/perolehan, pemrosesan, pendistribusian pengetahuan yang melibatkan pasar, produk, teknologi, dan proses bisnis kepada seluruh organisasi (Slater \& Narver, 1994b). Informasi yang diperoleh harus didistribusikan kepada para pembuat keputusan secara efisien jika mereka memiliki peluang untuk menggunakannya secara efektif (Sinkula et al., 1997). 
Dengan demikian, para peneliti telah menyimpulkan bahwa suatu orientasi pembelajaran mempengaruhi kepuasan suatu organisasi tentang seberapa proaktif pembelajaran terjadi, dengan demikian, mempengaruhi informasi yang pada akhirnya digunakan, diterima atau ditolak, dan dievaluasi (Day, 1991, 1994b; Senge, 1990; Sinkula et al., 1997). Oleh karena itu hipotesis yang diajukan adalah, H3: Orientasi Pembelajaran berpengaruh terhadap Orientasi Pasar

\section{Hubungan antara Orientasi Pembelajaran dan Modal Relasional}

Dalam suatu organisasi diperlukan suatu proses pembelajaran untuk meningkatkan pemahaman pemasar tentang memproses informasi dan menciptakan pengetahuan-pengetahuan baru dalam organisasi sehingga melalui orientasi pembelajaran atau learning orientation, perusahaan dapat meyalurkan, menginterprestasikan, dan mencapai kinerja yang diinginkan (Sinkula, 1994). Dengan demikian hipotesisnya adalah, H4: Orientasi Pembelajaran berpengaruh terhadap Modal Relasional

\section{Hubungan antara Modal Relasional dan Kinerja Keuangan}

Relationship adalah salah satu alat promosi yang paling efektif terhadap biaya dan waktu, terutama dalam membangun hubungan, preferensi, keyakinan antara konsumen dengan perusahaan (Lin, 2001). Relationship dapat pula bertujuan untuk membangun hubungan (network) yang efektif dengan stakeholder untuk waktu yang panjang dan saling menguntungkan (Kotler, 2000).

Perusahaan, termasuk bank syariah yang mempunyai perhatian tinggi pada terjalinnya hubungan yang harmonis jangka panjang dengan pelanggannya berlandasakan nilai-nilai kasih sayang, yang saling menguntungkan dan adil akan memberikan pengaruh yang signifikan terhadap efektivitas organisasi penjualan, melalui keinginan untuk memahami kebutuhan dan keinginan pelanggan, untuk menerapkan strategi penjualan sesuai dengan pendekatan manajemen penjualan yang diharapkan, sehingga dapat membangun kerjasama dan hubungan jangka panjang dengan pelanggan untuk meningkatkan kinerja keuangan. Dari uraian di atas dapat dirumuskan hipotesis, H5: Modal Relasional berpengaruh terhadap Kinerja Keuangan. 


\section{Metode Penelitian}

\section{Desain Penelitian}

Penelitian ini merupakan penelitian kuantitatif, yaitu penelitian ilmiah yang sistematis terhadap bagian-bagian dan fenomena serta hubungan-hubungannya. Tujuan penelitian kuantitatif adalah mengembangkan dan menggunakan model-model matematis, teori-teori dan/atau hipotesis yang berkaitan dengan fenomena keberadaan bank syariah.

\section{Teknik Pengumpulan Data}

Data yang digunakan dalam penelitian ini merupakan data primer, yang didapatkan langsung dari para responden melalui penyebaran kuesioner. Kuesioner disebar kepada para pimpinan atau pengambil kebijakan bank syariah di provinsi Jawa Tengah. Populasi dari penelitian ini adalah pimpinan Bank Umum Syariah di wilayah Jawa Tengah. Penentuan jumlah sampel dalam penelitian ini dilakukan dengan beberapa pertimbangan.

Teknik sampling yang digunakan dalam penelitian ini adalah metode purposive random sampling dan dalam penelitian ini elemen populasi yang dipilih berdasar sampel dibatasi pada elemen-elemen yang dapat membentuk informasi berdasarkan pertimbangan tertentu. Penentuan sampel dilakukan dengan menetapkan sejumlah kriteria. Kriteria sampel tersebut adalah, 1). responden minimal mempunyai jabatan middle management di bank umum syariah, 2) responden mengendalikan bank umum syariah di wilayah provinsi Jawa Tengah. Pemilihan metode ini salah satunya dilatarbelakangi keterbatasan waktu dan biaya penelitian, namun pertimbangan dan representasi populasi diharapkan tetap tidak terganggu.

\section{Deskripsi Data}

Distribusi data responden berdasarkan asal kota dan bank syariah disajikan dalam Tabel 3. 
Tabel: 3

\section{Distribusi Responden Bank Syariah}

\begin{tabular}{clcc}
\hline No & \multicolumn{1}{c}{ Nama Bank Syariah } & Frekuensi & Persentase \\
\hline 1 & Bank Syariah Mandiri & 15 & 12,61 \\
2 & BRI Syariah & 15 & 12,61 \\
3 & BTN Syariah & 12 & 10,08 \\
4 & Bank Mega Syariah & 10 & 8,40 \\
5 & Bank Niaga/CIMB Syariah & 9 & 7,56 \\
6 & Bank Muamalat Indonesia & 12 & 10,08 \\
7 & BNI Syariah & 12 & 10,08 \\
8 & Bank Jateng Syariah & 8 & 6,72 \\
9 & Bank Permata Syariah & 10 & 8,40 \\
10 & Bank NISP Syariah & 7 & 5,88 \\
11 & Bank Bukopin Syariah & 9 & 7,56 \\
& Jumlah & 119 & 100 \\
\hline
\end{tabular}

Sumber : data terolah

\section{Analisis}

Gambaran hasil pengolahan data untuk analisis Full Model SEM dapat dilihat pada gambar 1 ;

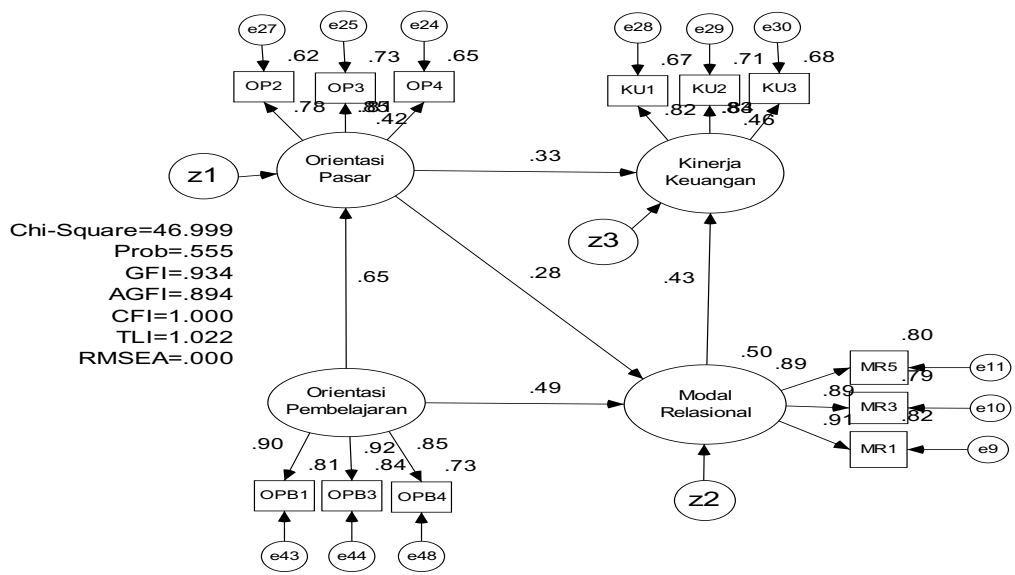

Sumber: data yang diolah, 2012

Gambar: 1

\section{Hasil Uji Structural Equation Model Full}


Uji terhadap kelayakan Full Model SEM ini diuji dengan menggunakan Chi Square, CFI, TLI, CMIN/DF dan RMSEA berada dalam rentang nilai yang diharapkan, meskipun GFI dan AGFI diterima secara marginal, sebagaimana tampak pada Tabel 3 berikut ini :

Tabel: 3

\section{Goodness of Fit Index Full Model}

\begin{tabular}{|c|c|c|c|}
\hline $\begin{array}{l}\text { Goodness of } \\
\text { Fit Index }\end{array}$ & Cut-off Value & $\begin{array}{c}\text { Hasil } \\
\text { Analisis }\end{array}$ & $\begin{array}{c}\text { Evaluasi } \\
\text { Model }\end{array}$ \\
\hline Chi-Square & $\mathrm{P}=5 \% \mathrm{df}=49$, Chi-Square $\leq 66.339$ & 46,999 & Baik \\
\hline Probabilitas & $\geq 0,05$ & 0,555 & Baik \\
\hline $\mathrm{CMIN} / \mathrm{DF}$ & $\leq 2,00$ & 0,959 & Baik \\
\hline GFI & $\geq 0,90$ & 0,934 & Baik \\
\hline AGFI & $\geq 0,90$ & 0,894 & Kurang Baik \\
\hline TLI & $\geq 0,95$ & 1,022 & Baik \\
\hline CFI & $\geq 0,95$ & 1,000 & Baik \\
\hline RMSEA & $\leq 0,08$ & 0,000 & Baik \\
\hline
\end{tabular}

Sumber : data primer yang diolah, 2012

Hasil pengolahan data menunjukkan tingkat signifikansi untuk uji hipotesis perbedaan di atas adalah $\chi^{2}=46,999$ dengan probabilitas sebesar 0,555 . Hal ini menunjukkan bahwa hipotesis nol yang menyatakan bahwa tidak terdapat perbedaan antara matriks kovarians sampel dan matriks kovarians populasi yang diestimasi gagal ditolak oleh karena itu kita menerima hipotesis nol. Indeks AGFI $(0,894)$ Kurang Baik, walau demikian indeks yang lain seperti CMIN/DF (0,959); GFI (0,934); TLI (1,022); CFI (1,000); dan RMSEA $(0,000)$ berada dalam rentang nilai yang diharapkan sehingga model ini bisa diterima.

Berdasarkan perhitungan melalui uji full model SEM, model ini dapat diterima. Selanjutnya berdasarkan model fit ini akan dilakukan pengujian hipotesis yang diajukan dalam penelitian ini. Hasil pengujian hipotesis dengan SEM disajikan dalam Tabel 4 berikut: 
Tabel: 4

Hasil Pengujian Hipotesis

\begin{tabular}{|c|c|c|c|c|c|}
\hline & & Estimate & S.E. & C.R. & $\mathrm{P}$ \\
\hline Orientasi_Pasar & Orientasi_Pembelajaran & .494 & .088 & 5.586 & $* * *$ \\
\hline sional <--- & entasi_Pasar & .264 & .115 & 2.297 & .022 \\
\hline Modal_Relasional <--- & Orientasi_P & .350 & .084 & 4.147 & $* * *$ \\
\hline Kinerja_Keuangan <--- & Modal_Relasional & .575 & .171 & 3.372 & $* * *$ \\
\hline Kinerja_Keuangan <--- & Orientasi_Pasar & .419 & .165 & 2.546 & .011 \\
\hline
\end{tabular}

Sumber : data primer yang diolah, 2012

Parameter estimasi antara orientasi pasar dengan kinerja keuangan menunjukkan hasil yang signifikan dengan $\mathrm{CR}=2,546$ atau $\mathrm{CR} \geq \pm 2,00$ dengan taraf signifikansi sebesar 0,011 (5\%). Dengan demikian Hipotesis 1 diterima. Parameter estimasi antara orientasi pasar dengan Modal Relasional menunjukkan hasil yang signifikan dengan $\mathrm{CR}=2,297$ atau $\mathrm{CR} \geq \pm 2,00$ dengan taraf signifikansi sebesar 0,022 (5\%). Dengan demikian Hipotesis 2 diterima. Parameter estimasi antara orientasi pembelajaran dengan orientasi pasar menunjukkan hasil yang signifikan dengan $\mathrm{CR}=$ 5,586 atau CR $\geq \pm 2,00$ dengan taraf signifikansi sebesar 0,000 (5\%). Dengan demikian Hipotesis 3 diterima. Parameter estimasi antara orientasi pembelajaran dengan modal relasional menunjukkan hasil yang signifikan dengan $\mathrm{CR}=4,147$ atau $\mathrm{CR} \geq \pm 2,00$ dengan taraf signifikansi sebesar 0,000 (5\%). Dengan demikian Hipotesis 4 diterima. Parameter estimasi antara modal relasional dengan kinerja keuangan menunjukkan hasil yang signifikan dengan CR $=3,372$ atau $\mathrm{CR} \geq \pm 2,00$ dengan taraf signifikansi sebesar 0,000 (5\%). Dengan demikian Hipotesis 5 diterima.

Orientasi pasar berpengaruh secara signifikan terhadap Kinerja Keuangan bank syariah. Ini berarti semakin tinggi derajat orientasi pasar maka akan meningkatkan kinerja keuangan bank syariah. Orientasi pasar sering dikatakan sebagai faktor yang sangat penting dalam mewujudkan kinerja yang superior dan kesuksesan jangka panjang dari suatu perusahaan dalam lingkungan persaingan yang semakin meningkat.

Orientasi pasar berpengaruh secara positif terhadap modal relasional. Hal ini berarti bahwa semakin tinggi orientasi pasar, 
semakin tinggi pula modal relasional yang diperlukan. Sebagaimana dikemukakan oleh Houston (1986), bahwa konsep pemasaran dipandang sebagai filosofi terbaik untuk melakukan bisnis dan merupakan bagian inti dari budaya organisasi yang berhasil. Selanjutnya dikemukakan bahwa filosofi bisnis lebih menunjuk pada serangkaian tata nilai dan kepercayaan, sikap dan budaya perusahaan, maka untuk memberikan kontribusi pada tataran operasional berupa serangkaian aktivitas-aktivitas pengelola bisnis, orientasi pasar juga dipahami sebagai perilaku atau aktivitas-aktivitas. Dengan demikian dalam memahami kebutuhan pelanggan, bank syariah juga harus memperhatikan budaya masyarakat yang sudah dan akan menjadi nasabahnya. Nasabah akan mudah diperoleh dengan memperhatikan nilai-nilai budaya, agama, kepercayaan, yang dijunjung tinggi.

Orientasi Pembelajaran berpengaruh terhadap orientasi pasar. Ini berarti bahwa semakin tinggi derajat orientasi pembelajaran maka akan meningkatkan orientasi pasar. Seorang pimpinan bank syariah mestinya memiliki orientasi pembelajaran yang tinggi sesuai dengan tuntutan pekerjaan yang dihadapi dan menjadi tanggung jawabnya. Dengan orientasi pembelajaran ini maka akan meningkatkan orientasi pasar. Orientasi pasar adalah menjadi fokus atau sasaran bagi setiap perusahaan. Keberhasilan lembaga perbankan syariah sangat dipengaruhi oleh para nasabahnya, oleh karena itu masalah orientasi pembelajaran haruslah menjadi perhatian bagi manajemen perbankan syariah.

Orientasi pembelajaran berpengaruh secara positif terhadap modal relasional. Ini berarti bahwa semakin tinggi derajat orientasi pembelajaran maka akan semakin meningkatkan modal relasional bank syariah. Orientasi pembelajaran berarti memiliki kemampuan dan kemauan untuk terus melakukan inovasi dan selalu belajar dari pengalaman dalam mengelola bisnis perbankan, kemampuan berkomunikasi, kemampuan membangun jaringan bisnis, kemampuan bekerja sama, memiliki kemampuan di bidang teknis dan lain-lain. Dengan kemauan untuk terus belajar tersebut maka dalam meningkatkan modal relasional dengan pelanggan akan semakin baik atau lebih berkualitas. 
Modal relasional berpengaruh secara signifikan terhadap kinerja keuangan bank syariah. Ini berarti bahwa semakin tinggi modal relasional, semakin tinggi kinerja keuangan bank syariah. Kinerja perusahaan merupakan akumulasi dari hasil aktivitas yang dilakukan dalam perusahaan, yang merupakan refleksi dari pencapaian kuantitas dan kualitas pekerjaan yang fihasilkan individu, kelompok, atau organisasi dan dapat diukur. Demikian juga dikemukakan oleh Wells dan Spinks (1996) bahwa kinerja menunjukkan hasil-hasil perilaku yang bernilai dengan kriteria atau standar mutu. Kinerja akan sangat ditentukan oleh semua sumber daya manusia yang ada di perusahaan. Kinerja akan meningkat bila memiliki sumber daya yang tangguh, tetapi semua perilakunya didasari oleh norma-norma kasih sayang, persaudaraan, saling percaya, dan mereka merasa diuntungkan.

\section{Kesimpulan}

Penelitian ini berupaya membangun sebuah model untuk meningkatkan kinerja keuangan perbankan syariah melalui pendekatan orientasi pemasaran, orientasi pembelajaran, dan modal relasional pada perbankan syariah dan unit usaha syariah di Propinsi Jawa Tengah.

Orientasi pasar berpengaruh secara signifikan terhadap kinerja keuangan bank syariah. Ini berarti semakin tinggi derajat orientasi pasar maka akan meningkatkan Kinerja Keuangan bank syariah. Orientasi pasar berpengaruh secara positif terhadap modal relasional. Hal ini berarti bahwa semakin tinggi orientasi pasar, semakin tinggi pula modal relasional yang diperlukan. Orientasi Pembelajaran berpengaruh terhadap orientasi pasar. Ini berarti bahwa semakin tinggi derajat orientasi pembelajaran maka akan meningkatkan orientasi pasar. Orientasi pembelajaran berpengaruh secara positif terhadap modal relasional. Ini berarti bahwa semakin tinggi derajat orientasi pembelajaran maka akan semakin meningkatkan modal relasional bank syariah. Orientasi pembelajaran berarti memiliki kemampuan dan kemauan untuk terus melakukan inovasi dan selalu belajar dari pengalaman dalam mengelola bisnis perbankan, kemampuan berkomunikasi, kemampuan membangun jaringan bisnis, kemampuan bekerja sama, memiliki kemampuan di bidang teknis dan lain-lain. Modal 
relasional berpengaruh secara signifikan terhadap kinerja keuangan bank syariah. Ini berarti bahwa semakin tinggi modal relasional, semakin tinggi kinerja keuangan bank syariah. Kinerja perusahaan merupakan akumulasi dari hasil aktivitas yang dilakukan dalam perusahaan, yang merupakan refleksi dari pencapaian kuantitas dan kualitas pekerjaan yang fihasilkan individu, kelompok, atau organisasi dan dapat diukur.

Penelitian yang akan datang direkomendasikan mencakup bank syariah di wilayah lain yang memiliki karakteristik yang berbeda, serta responden yang tidak hanya pemimpin bank syariah.

\section{Daftar Pustaka}

Akinova, I. 2000. "Development of market orientation and competitiveness of Ukrainian firms". European Journal of Marketing. Vol. 34, pp. 1128-1148.

Ariff, M. 1988. Islamic Banking in Southeast Asia: Islam and the Economic Development of Southeast Asia. Social Issues in Southeast Asia. Institute Of Southeast Asian Studies.

Asikhia, O. 2010, "Customer Orientation and Firm Performance among Nigerian Small and Medium Scale". Management, Vol. 38, pp.773788.

Asikhia, O. U. 2010. "Banks Market Orientation and Performance Relationship in Nigeria". Journal of Management and Society. Vol. 1, No. 2, pp. 01-08.

Bank Indonesia. 2011. Statistik Bank Syariah.

Bhuian, S.N. 1998. "An Empirical Examination Of Market Orientation In Saudi Arabian Manufacturing Companies". Journal of Business Research, Vol. 43, No. I, pp.13-25.

Bhuian, Shahid N, Menguc, Bulent and Bell, Simon J., 2005. Just Entrepreneurial Enough: The Moderating Effect of Entrepreneurship on the Relationship between Market Orientation and Performance. Journal of Business Venturing, Vol. 58, Issue 1, p. 9-17

Caruana, A. Pitt, L. F. and Berthon, P. R. 1999, "The Excellence - Market Orientation Link: Some Consequences For Service Firm”. Journal of Business, Vol. 44. Issue 1. pp 5-15.

Day, G. S., Prakash N. D, George S. and Prakash, N. 1994. "Managerial Representations of Competitive Advantage." Journal of Marketing,Vol. 58, pp. $31-44$ 
Deshpandé, R., J. U. Farley. and F. E. Webster, Jr. 1993. "Corporate Culture, Customer. Orientation, and Innovativeness in Japanese Firms: A Quadrad Analysis". The Journal of Marketing, Vol. 57, No. 1 pp. $23-37$

Deshpandé, Farley, and Webster. 1993. "A Factor A Competitive Entities To Satisfy These Needs". Journal of Business Research 48.

Deshpande, R and Farley, J. U. 1998. "Measuring Market Orientation: Generalization and Synthesis". Journal of Market Focused Management, Vol. 2, No.3, pp. 213-232.

Ellis, P. F and Huw Lloyd. 2006. "Intrinsic Business Cycles with Pro-Cyclical RED," Working Papers 1102

Gainer, B and P.Padanyi. 2005. "The Relationship Between MarketOriented Activities And Market-Oriented Culture: Implications For The Development Of Market Orientation In Nonprofit Service Organizations". Journal of Business Research. Vol. 58 (2005), pp. 854- 862.

Gebhardt, Carpenter dan Sherry. 2006. "Creating a Market Orientation : A Longitudinal, Multi-firm, Grounded Analysis of Cultural Transformation". Journal of Marketing. Vol. 2, Issue 4.

Gray. B. J. Gray and Hooley, G. J. 2002. "Guest Editorial: Market Orientation And Service Firm Performance - A Research Agenda", European Journal of Marketing. Vol. 36, pp.980 - 989

Han, IK; Kim, N. and Srivastava, R. K. 1998. "Market Orientation And Organizational Performance: Is Innovation A Missing Link?" Journal of Marketing, Vol. 62, October, pp. 30-45.

Hardley, F. and Mavondo, F. (2000). The Relationship between Learning Orientation, Market Orientation and Organisational Performance, paper presented at the Australian \& New Zealand Marketing Academy Conference, Queensland, Australia.

Hart, S. and Diamantopolous, A. 1993. "Linking Market Orientation and Company Performance: Preliminary Work On Kohli and Jaworski's Framework". Journal of Strategic Marketing, Vol. 1, No. 2, pp. 93-122.

Homburg, C. and Pflesser, C. 2000. "A Multiple-layer Model of MarketOriented Organizational Culture: Measurement Issues and Performance Outcomes". Journal of Marketing, Vol. 37. No. 4. pp 462-462.

Hunt, S. D. and Morgan, R. M. 1995. "The Comparative Advantage Theory of Competition." Journal of Marketing. Vol. 59, pp. 1-15. 
Jaworski, Bernard. J., Ajay K. Kohli, and Arvind Sahay. 2000. "Market Driven V.S Driving Markets". Journal of the Academy of Marketing Science, Vol. 26, p.65

Jaworski, B. I. and Kohli, A. K. 1993. "Market Orientation: Antecedents and Consequences". Journal of Marketing. Vol. 57, pp. 53-70.

Kara, A., Spillan, J.E., and DeShields Jr. O.W. 2004. "An Empirical Investigation Of The Link Between Market Orientation And Business Performance In Non-Profit Service Providers".Journal of Marketing Theory \& Practice. Vol. 12,No. 2, pp. 59-72.

Kirca, A.H., Jayachandran, S. and Bearden, W. O. 2005. "Market Orientation: A Meta-Analytic Reviewand Assessment Of Its Antecedents And Impact On Performance". Journal of Marketing. Vol. 69, pp. 24-41.

Kotler, Philip, 2000. Marketing Management, The Millenium Edition, New. Jersey: Prentice Hall International, Inc.

Lado, N., Maydue-Olivares, A., Rivera, J., 1998. "Measuring Market Orientation in Several Population: a Structural Equation Model". The European Journal of Marketing". Vol. 32 (1), pp. 23-39.

Narver, J. C., and Slater, S. F. 1990. "The Effect Of A Market Orientation On Business Profitability". Journal of Marketing, Vol. 54(4), pp. 2035.

Ruekert, R W. (1992) Developing A Market Orientation: An Organizational Strategy Perspective. International Journal of Research in Marketing, Vol. 9,August, pp. 225-245

Schwandt, D. R., and Marquardt, M. J. 2000. "Organizational Learning: From World-class Theories to Global Best Practices. St. Lucie Press: Boca Raton.

Senge, P.M. 1990." The Fifth Discipline". New York, NY: Doubleday/ Currency.

Sinkula, J. M., Baker, W. E., Noordeweir, T. 1997. "A Framework For Market-Based Organisational Learning: Linking Values, Knowledge, And Behaviour". Journal of the Academy of Marketing Science, Vol. 25,pp.305G 318.

Slater, S. F. and Narver, J. C. 1994. "Does Competitive Environment Moderate The Market Orientation Performance Relationship?". Journal of Marketing. Vol. 58, January, pp. 46- 55.

Woodruff, Robert B. and Sarah Fisher Gardial. 1996. Know Your Customer: New Approaches to Understanding Customer Value and Satisfaction. Publication Date: June 10, 1996 I ISBN-10: 1557865531 I ISBN-1 